\title{
Impact of Class Atmosphere on the Quality of Learning (QoL)
}

\author{
Nader Ofoghi, Abbas Sadeghi, Maryam Babaei \\ University of Guilan, Rasht, Iran \\ Email: asadeghi1394@gmail.com
}

How to cite this paper: Ofoghi, N., Sadeghi, A., \& Babaei, M. (2016). Impact of Class Atmosphere on the Quality of Learning (QoL). Psychology, 7, 1645-1657. http://dx.doi.org/10.4236/psych.2016.713156

Received: October 8, 2016

Accepted: November 15, 2016

Published: November 18, 2016

Copyright $\odot 2016$ by authors and Scientific Research Publishing Inc. This work is licensed under the Creative Commons Attribution International License (CC BY 4.0).

http://creativecommons.org/licenses/by/4.0/

(c) (i) Open Access

\begin{abstract}
Learning is the most important issue in teaching and regarding class atmosphere is one of the main issues that has special place in partial quality of learning. This study was performed to investigate the relationship of Atmosphere on the Quality of Learning (QoL). This study was done in Guilan University of Guilan that about 0.5 of students were selected through cluster sampling method with regard to the size of population (7200 students) and through systematic random sampling. 360 persons were selected and 357 questionnaires were filled and returned among 360 distributed questionnaires in various disciplines. Also 35 academic staffs (about 0.1 ) were participated in this research for conducting interview. Instruments for collecting the information of questionnaire have been researcher-made and interview. Descriptiveanalytic method has been used in this research. In all cases null hypotheses rejected and research hypotheses were confirmed. Also in analysis of interview with academic staffs that questions were related to research main hypotheses, much emphasis has been put on the effect of factors influencing on class atmosphere and quality of teaching and learning. It should be stated that there is a positive and direct relationship between class atmosphere and its factors (order and organization in class, clearness of rules in class academic staff control over the class, academic staffs and student mutual respect) and quality of learning.
\end{abstract}

\section{Keywords}

Class Atmosphere, Quality, Learning, Teaching University

\section{Introduction}

A successful educational system helps the person to flourish his/her natural talent and also educates him/her as a person aware of global issues and responsible for values of a society that is attached to it (Seif, 2011). In fact teaching and training is a social process 
in which person reaches to social competence and personal growth. This process that is conducted by an institution like university (Safavi, 2014) is the most main factor for creating success in achieving educational goals that can provide good condition for achieving better learning by controlling various variables. Professor can compensate the inaccuracy of textbook and lack of educational facilities or reverse, convert the best success and teaching subject by inability in creating favorable emotional relevance with inactive and unattractive environment (Mazloomi Mahmood Abad et al., 2010).

Teaching is a conscious activity that is conducted based on particular goals and cognitive status of students and makes change in them (Shabani, 2013). In general definition, effective teaching should be regular and encouraging and causes students interest. (Brown \& Atikson, 2003). Skill contexts determine effectiveness of every teacher such as: (A-competence and technical ability) knowledge and skill in course and education, (B-competence and professional ability) being aware of planning, presenting and educational evaluation (C-personal competence) effective personal and behavioral characteristics in teaching and training process) (Miller \& Miller, 2004, quoted from Andelib \& Ahmadi, 2007). Nowadays much more attention is paid to quality of teaching and learning in all universities in the world; also ensuring effective teaching and demonstrating this effectiveness in universities have great importance (Devlin \& Samarawickrema, 2010).

Experience shows that, little attention is paid to teach basic skills and much part of this ability has been neglected at University of Guilan classes. Perhaps the reason for this problem is non-human sciences faculty and sometimes other professors at University of Guilan that during university and higher education have not passed any course related to class management.

\section{Dimensions of Class Atmosphere}

Namely order and organization in class, clearness of rules in class, professor's control over the class and professor and student mutual respect known as Dimensions of class atmosphere.

Class atmosphere has a direct relationship with teacher management style. Teacher creates attractive class by applying proper management skills that makes positive and active relationships between him/her and his pupils. In class atmosphere task and organizing class has a main role in students learning teachers have attractive, task-oriented and completely organized class by combining these three factors.

In attractive classes there is a positive and active relationship along with mutual respect, cooperation and inner satisfaction. These classes are directed to specific goals. Teacher and pupil are responsible for achieving goals by spending time and mental attention. Thus, in organized classes behavioral and learning expectations are quite clear and tangible and teacher provides proper structure for teaching and training course concepts and subjects.

Since the professor deals with students' spirit, mind and emotions, if he/she doesn't function properly, it will leave irreparable losses (Asadi Noghabi et al., 2013). In fact the 
academic staffs' performance and characteristics that leads to achieve educational goals and student learning. For this reason, character is tics of effective teacher are considered by many researches in the world (Asgari \& Mahjoob Moadab, 2010).

Researches have presented a comprehensive image of related and available factors and components about teaching at universities and higher education centers and key features of effective teachers. The most important of these factors in internal studies are eloquent and simple expression, clear and explicit conveyance of materials, easy access to professor out of regular class hours and students evaluation in each session, midterm and final (Read Abadi et al., 2012), interpersonal relationship, Teaching skills, personal traits, evaluation skill and considering educational rules (Mir Mohammadi Mobidi et al., 2012), mastery of content, skills of presenting content, course management, guidance and counseling, evaluation of learning, communication skills, and considering moral issues in educating and teaching (Safari, 2011).

Eiszler (2000) believes that professors teaching quality is as an important factor that should be considered as a part of university goals because its outcome is favorable quality of learning and in higher education center its defined as a ground for improving effective learning opportunities for students (Shabani, Bakhtiyari, \& Hosein Gholizadeh, 2006). Since professors quality of training and ability to create profound perception and power of analysis in comparison with presented contents in students are more important than learning (Rahimi et al., 2002) professor s series of behaviors and performances as a part of quality of teaching results in achieving better educational and learning goals that includes indicators and various traits (Jones, 2003).

It can be said that quality of learning is determined and evaluated in the light of contrast among general criteria such as design of teaching, performance of teaching, class management, human relationships, evaluation and desirable personality traits. in the other words, an effective teacher is a person who presents in class with and works on presenting effective training based on designing of that course and with this goal considers mastery of course subject and specialty in teaching process with determining opportunity to speech, having high and reasonable expectations and the same cases (Bowen, 2013).

Also supervision and control is one of teacher's duty and responsibilities because discipline and order and class management are effective in a good learning environment. Class management is always the most important issues for teachers because class management and control is always a prerequisite in effective learning environment for achieving educational goals. Organizing the classroom makes the class management easier. This activity should be designed in such a way that creates more learning opportunities through it and increases and improves learners' social and cooperative skills (Samadi et al., 2008).

Professor should create a happy and attractive environment in class and also have effective behavior toward possible disorders, preserve constructive and mutual relationships with students inside and outside environment of class, solve students and even his/her teaching mistakes by making proper evaluations and provide on time feedback 
and at the same time have stable personality and competent characteristics of a teacher (Salimi \& Ramzani, 2014). Here it should be mentioned that notice to quality aspect of training with regard to its importance in students training and (earning as the main outcome and output is upon this system, has got much more importance (Hussey \& Smith, 2010).

What has been considered by researchers as the central and main point in this study is that if great masters notice to effective factors of teaching in learning process, apply those factors in class and teaching it will create desirable mental conditions, so students will have favorable and good condition. For this parameters of these factors from recent course planners viewpoint with constructivism aspect. This prospective hypotheses that emphasize on class based and orbital process, make the teacher or professor to determine and state guidance of syllabus and provide proper training materials with syllabus (Falavel, 1998).

One of approaches that has been posed in the case of existed condition in class is interactionism approach. This approach is placed between the two approaches of interventionism and non-interventionism and is based on presuppositions of social psychological theory According to this approach, learners learn through active relationship with other (teacher or classmates). This theory emphasizes on both activities that person does to change the environment and notices to environmental factors that affect person (Gelaser, 2009). Studies have shown that advantages and positive aspects of interactive management style is much more than intervention and non-intervention style. Furthermore, professors and students have much satisfaction from interactive style. In fact when professors use interactive style, students' academic progress level is at its highest (Amini et al., 2015). Kukuru (2011) has concluded in his research that classroom and course management is a ground for effective and qualitative training and ensuring of creating a healthy classroom environment without flaw.

Rogers (2000) with constructive theory believes that this approach considers professors and teachers responsible toward responses and states that how can we wake learners ready for every change? How can we meet all learners' expectations? And how can we be sure that learners learn what is necessary? He emphasizes on important effective resources and factors toward about questions. Coombs (1971) believes that teachers or professors shouldn't only rely on one special skill to manage the class but it's their ability in using a series of various skills and knows these skills such as ability to prepare the class (favourable learning condition) planning on learning pattern, strategies and class activities especially making learners ready to participate in performing tasks and emphasizes that we can easily create mental conditions in learning process by effective applying of time, place and facilities and correct management.

In Nazari Vanani et al. (2014) that effective factors on presenting in class is considered from their perspective was reported as motivating by professor. Researches have shown that students are indifference toward posed issues at the first of class, but professors should motivate in learners by different ways and draw their attention by telling the importance and course usage in future job. Professors' awareness and knowledge 
toward the whole class, using clear and defined signals to draw learners' attention, keeping class activities in active and happy from and making variety in class activities are effective in drawing learners' attention.

Rana and Akbar (2007) and Lizzio, Wilson and Simons (2002) researched have been conducted in relation to class environment and students' academic performance and all finding indicate that facilitate pleasant class environment, academic performance and them learning. In addition to relationship of class environment with academic performance, it also has relationship of class environment with academic performance, it also has relationship with variables of advanced goals and reflective thinking. Green et al. (2004) research environment influences on selecting the type of their progress goal.

With regard to what has been stated, this research goal is to investigate the relationship between class atmosphere and students learning quality at university of Guilan. Researchers hope that this result could create good change in training classes and leads it to its predetermined goals.

\section{Research Hypotheses}

In this research well investigate following hypotheses:

First hypothesis: there is a significant relationship between order and organization in class and students learning quality.

Second hypothesis: there is a significant relationship between clearness of rules in class and students learning quality.

Third hypothesis: there is a significant relationship between professor s control over the class and students learning quality.

Fourth hypothesis: there is a significant relationship between professor and student mutual respect and student learning quality.

\section{Methodology}

This research is descriptive-analytic kind that is conducted to influence the evaluation of two variables (class atmosphere and quality of learning). Target population of this research, were all students at colleges and various educational groups at university of Guilan (faculty of humanities, Agricultural Sciences, Basic Sciences, Technical, Natural Resources) that with regard to huge size of statistical population (7200 students) about 0.5 of students by cluster sampling method and systematic random sampling method were classified and selected as statistical sample.

As analysis unit in this research has been odd, then a proportion of students have been considered in determining sample size, The number of 360 persons were selected and 357 questionnaires were filled and returned among 360 distributed questionnaires in different fields Also 35 faculty members (about 0.1 out of whole faculty members at university of Guilan) were participated in this research.

\section{Research Instruments}

1) Researcher-made questionnaire: Because descriptive-analytic method has been 
used in this research that researchers' goal is objective, real and regular description of a situation or issue, questionnaire has been used for achieving real information.

Naderi and Seif Naraghi (1987), Tajdarai (1990) cooperation office of area and university (1984) emphasize that questionnaire is as a paper or notebook that a version of it is determined to every survey or unit and is equal to all people.

Main research questionnaire is designed in such a way that its questions are stated based on hypotheses, Also, the questionnaire contained questions about the context variables that based on some demographic information about the academics were collected. Questionnaire has 49 questions and answer in table has been set by (absolutely agree, agree, I'm not sure, disagree and absolutely disagree) that absolutely disagree to absolutely agree that the score is 1 to 5 .

2) Interview: Interview was applied as the second instrument of this research that was considered as complementary instrument. Interview with dear faculty members was about the impact of mental state of on quality of learning. This instrument that is used rarely, has been one of the important instrument for making sure of research and collecting information of this research.

a) Professor and student mutual respect 2.5 and Chronbach's Alfa coefficient has been about 0.86 in this change that shows reliability in high level.

b) Order and organization in class, mean is about 2.5 and Chronbach's Alfa coefficient 0.66 that the removal of question 33 and 35 to 0.7 .

c) Academic staffs' control over the class, mean is about 2.5 and Chronbach's Alfa coefficient 0.74 .

d) Clearness of rules is about 2.15 and Chronbach's Alfa coefficient 0.83 in extremely high level.

As it is observed all questions related to hypotheses have high reliability.

\section{Findings}

A-Description of data: This study has been conducted based on information of data related to 357 respondents at University of Guilan that among all respondents, 208 persons have been female (0.583) and 149 persons male (0.417). Range of age changes in under study statistical population has been between less than 20 to upper than 35 years that the most percent with 0.762 is related to age group of $20-25$ and the least with 0.06 related to upper than 35 years from age frequency. In the other words, distribution of sample population that indicates the most observations is about between 22 to 33 , which is the most respondent students are this range of age.

B-Quality of learning: students learning frequency distribution is presented in following Table 1 that was evaluated as two-item questions of Yes/No.

Table 1 below shows that most students, that is about $64.7 \%$ of them have known classrooms as having quality and about $35.3 \%$ of them have known classrooms no quality.

A-Questions of questionnaire: Descriptive results of questionnaire indicate that the mean of whole item scores of Likert spectrum related to questions of questionnaire is 
Table 1. Respondents frequency distribution in terms of quality of learning.

\begin{tabular}{cccc}
\hline & Frequency & Percent & \\
\hline Yes & 231 & 64.7 & 64.7 \\
No & 126 & 35.3 & 100 \\
Total & 357 & 100 & \\
\hline
\end{tabular}

tended toward higher than average, that is (3) and is much closer to agree response and from distribution aspect, all questions have negative skewedness except question 7 that has positive skewedness that is a kind of determiner of mean of whole scores, that is scores are tended toward agree and completely agree.

B-Data analyses: In this section, first research hypotheses were examined and with regard to two-dimensionality of table for analyzing research data, two-dimension test $x^{2}\left(k^{2}\right)$ has been used and then research questions were examined that with regard to three-dimensionality of table for analyzing data, three-dimension test $x^{2}$ has been used. Also, for evaluating intensity of correlation among research variables either in two-dimeusion tables or three-dimension tables, Cramer; $\mathrm{V}$ index has been used for being rectangularity of tables.

With regard to above Tables 2-5, analysis of all research hypotheses show that research hypotheses were emphasized In the other words, test results indicate that research hypotheses such as professors control over the class and mutual respect between professor and student, with 0.95 of confidence have relationship with quality of learning, if mentioned cases get more support, quality of learning in students also get that much support. Generally results indicate that improvement of psychological conditions of class in learning is highly effective in increasing quality of learning.

\section{Discussion and Conclusion}

1) General conclusion (questionnaires): This research was conducted to investigate the association between class atmosphere and students quality of learning at University of Guilan in which order and organization, clearness of rules, professors control over the class and mutual respect between professor and students and students together were pointed out as the most effective factor on quality of learning and two means of questionnaire and interview were used. Quantitative analysis of this research shows that all research hypotheses indicate that research hypotheses were certified.

Comparison between tests, hypotheses, research questions and theorists' perspectives indicates that the result of first hypothesis (order and organization of class) certifies Kalahan's theory (1989) that emphasizes on mental health of learners in the light of regular training and exact control of class and calls it as democratic discipline. According to Dabiri Esfahani (2006) discipline problems in class and in fact lack of a suitable organization in educational environment that its goal is personality growth and effective learning, are the main problems. Class incompatibilities and discipline problems are such cases that make problem for this process (learning) and result in extra problems in educational environment (Aman Elahi et al., 2009). Also Weille and Doyle (2000) know 
Table 2. Investigation the association between the effect of order and organization of class and quality of learning.

\begin{tabular}{ccccc}
\hline Total & High & Average & Low & $\begin{array}{c}\text { Order and organization of class and } \\
\text { learning quality }\end{array}$ \\
\hline 231 & 128 & 92 & 11 & Yes \\
& 0.74 & 0.568 & 0.5 & No \\
126 & 45 & 70 & 11 & Total \\
357 & 0.26 & 0.432 & 0.5 & Test result \\
Soo1.o $=$ ig & $x^{2} 13.055=\mathrm{m}$ & Df $=2$ & $5 \%=\mathrm{a}$ & Intensity of correlation \\
SIG $=$ & 0.001 & Cramer's V & 0.191 &
\end{tabular}

Table 3. Investigation the association between clearness of rules and quality of learning.

\begin{tabular}{ccccc}
\hline Total & High & Average & Low & $\begin{array}{c}\text { Clearness of rules and } \\
\text { quality of learning }\end{array}$ \\
\hline 231 & 124 & 99 & 8 & Yes \\
& 0.734 & 0.563 & 0.667 & No \\
126 & 45 & 77 & 4 & Total \\
357 & 0.266 & 0.438 & 0.333 & Test result \\
Sioo4.o $=\mathrm{g}$ & $\sigma^{2} 11.089=\mathrm{mx}$ & Df $=2$ & $0.5=\mathrm{a}$ & Intensity of correlation \\
\hline sig= & 0.004 & Cramer's V & 0.176 &
\end{tabular}

Table 4. Investigation the association between academic staffs' control over the class and quality of learning.

\begin{tabular}{ccccc}
\hline Total & High & Average & Low & $\begin{array}{c}\text { Professors control over the class and } \\
\text { quality of learning }\end{array}$ \\
\hline 231 & 147 & 73 & 11 & Yes \\
& 0.71 & 0.545 & 0.688 & No \\
126 & 60 & 61 & 5 & Total \\
357 & 0.29 & 0.455 & 0.313 & Test result \\
Sioo7.o $=\mathrm{g}$ & $\mathrm{o}^{2} 9.86=\mathrm{mx}$ & Df $=2$ & $0.5=\mathrm{a}$ & Intensity of correlation \\
sig $=$ & 0.007 & Cramer's V & 0.166 &
\end{tabular}

a proper class management as a factor for increasing good behavior and effective learning environment. According to Lowrin (2011) opinion in managing class, organization is a main and necessary issue, disregarding this issue in class results in the process of teaching and learning. Mullins (1991) believes that order and discipline and class management is effective in creating a suitable learning environment. 
Table 5. Investigation the association between professor and student mutual respect and quality of learning.

\begin{tabular}{ccccc}
\hline Total & High & Average & Low & $\begin{array}{c}\text { Mutual respect and quality } \\
\text { of learning }\end{array}$ \\
\hline 231 & 141 & 72 & 18 & Yes \\
126 & 0.754 & 0.514 & 0.6 & No \\
357 & 46 & 68 & 12 & Total \\
Sioo7.o $=\mathrm{g}$ & $\sigma^{2} 20.464=\mathrm{mx}$ & Df $=2$ & 0.4 & Test result \\
sig & 0.000 & Cramer's V & 0.239 & Intensity of correlation \\
\hline
\end{tabular}

Test result of the second hypothesis (clearness of rules in class) also proves Kalahan's opinion (1989) that emphasizes on training of learners by professor or teacher toward their responsibility for learning that itself results from clearness of rules. Wiles and Bandi (1994) quoted from Samadi et al. (2008) indicated that clearness of goals and educational rules is a purposeful means to help manage class and improve learning and training process. Also Evereston's researches (1987) about managing classroom showed that classroom requires clear and obvious rules and regulations that teachers should apply them to control the class and facilitate learning. In Kunter and others perspective (2007), knowledge and students perception from clearness of rules and teachers control have positive relationship with their interest in learning.

Test result of the third hypothesis (academic staffs control over the class) also proves Joseph Kalahan's perspective (1989) that points out self-confidence issue in teaching which itself is a factor of controlling professor. Wang et al. (1990) believe that managing classroom for creating the best possible environment for students learning is the first responsibility for teacher. Also Alavi Langeroodi and Soleimani (2012) in their research showed that as for teachers who are educated in majors related to teaching and training, their controlling style in class is interventionism and so they have positive effect on conditions of class and students learning.

Finally, test result of hypothesis 4 (mutual respect with students) also emphasizes on Argil's opinion (1977) that emphasizes on respect and attention to each of learners from professor or teacher side and attention to each of learners from professor or teacher side and also emphasizes on Hilgard and Bower (1992) and Dolor and Miller s opinion quoted from Seif (2007) that emphasizes on the base of reinforcement in learning process that calls such professors affability in answering learners questions and mutual respect, stimulus of reinforcement. Haerizade and other research (2010) as Investigation the effect of academic staff-student $s$ social relations on educational success showed that students' perspective toward professor and their mutual respect are such a kind of effective factors on their educational success. Also based on Ghadami et al. (2007) as effective factors on establishment the relationship between professor and stu- 
dent from students perspective at university of medical science in Arak, keeping students respect by professor is such the most effective factor in communicating from students' perspective.

Furthermore, comparison of results with research history shows thst this research results have much conformity with Ahmad Hojat Ansari's research results (1995) that had shown there is a significant association between mental-social condition of class and students educational progress. Also this research results is compatible with standards of states of America Skentucky (2002) and Wang and Hurtle's research results and conducted study in Kolkata. According to Larocque (2008) if the condition of classroom environment is such that teacher controls the whole class and his/her teacher covers the whole class, some students even those who have positive self-concept and are motivated as inner for learning, can nit easily concentrate on course home works, but when the condition is such that teachers teaching is done in small groups and evaluation is also a part of learning process, students organize their learning activities. Lewin and Murray have emphasized on the importance of environmental features in peoples behaviors theories of these researchers indicate that balance between environmental features (like class experiences) and personal traits are in fact predictor of human growth and his/her series of behaviors (Aldridge, Dorman, \& Fraster, 2004).

2) General conclusion (interviews): with regard to faculty members' perspective about effective mental condition on quality of learning, we can consider following general conclusion:

a) Without order and organization, class is not basically controllable and in addition to quantity and quality of learning, it has unbelievable effect.

b) Clearness of rules of class results in relaxation in professor and student and in fact helps both of them to move toward goals of class and qualitative improvement of learning.

c) academic staffs control over the class causes high efficiency and practicality of teaching And its result is improvement of quality of learning.

d) Mutual respect between academic staffs and student together results in mutual mental relaxation and has significant effect for improving quality of learning.

e) In addition to mentioned effective factors, there are 27 other important factors in improving quality of learning that the most important of them are self-confidence, being bold, having proper expression, having power of initiative by professor and existence of research in teaching and linking students mental conditions to external and home conditions.

With regard to mentioned history and achieved evidence from this research, about relations of class atmosphere and quality of learning, we can say that mental appropriate environment provided in class facilitates improvement in learning process, therefore it's necessary to do arrangements in order to improve this case at universities. Training in the form of conducting workshops on communication skills and teaching skills to professor is such an action. Also students could take step for meeting these cases by increasing cooperation and engagement in class issues. 


\section{References}

Alavi Langeroodi, S. K., \& Soleimani, Z. (2012). Comparison of Teacher Beliefs and Attitudes about Classroom Management with Regard to Demographic Features. Journal of Modern Scientific-Research Method in Educational Management.

Aldridge, J. M., Dorman, J. P., \& Fraser, B. J. (2004). Use of Multitrait-Multimethod Modeling to Validate Actual and Preferred Forms of the Technology-Rich Outcomes Focused Learning Environment Inventory (TROFLEI). Australian Journal of Educational and Developmental Psychology, 4, 110-125.

Aman Elahi, A., Atari, Y. A., \& Khojaste Mehr, R. (2009). Investigation the Association of Family Performance and Mental States of Class and Inconstancy among Students in the First Grade of High-School in Ahvaz, Development and Researches of consultation.

Amini, M., Rahimim, H., \& Gholamian Balzaki, Z. (2015). Investigation of Managing the Class Styles of Medical Science University Faculty Members in Kashan, Magazine of Development Steps in Medical Education.

Andelib, B., \& Ahmadi, G. (2007). Amout of Using Effective Teaching Criteria at Free Islamic University of Khorasgan from Students Viewpoint in Educational year 2006-2007. Journal of Knowledge and Research in Education Science.

Argil, J. A. (1977). Toward Realistic Communication Policies. Translator: Jahandari, Khoro, Communication Sciences Research Institute Press, Tehran, Iran, 7.

Asadi Noghabi, Ahmad Ali, Zandi, Mitra, Nazari, Ali Akbar (2013). Learning Process and Training Principles Patient. Tehran: Hakim Hijadi Press.

Asgari, F., \& Mahjoob Moadab, H. (2010). Comparison of Effective Teaching Features from Teachres and Students Viewpoint at Medical Science University of Guilan. Development Step in Medical Education.

Bowen, B. D. (2013). Measuring Teacher Effectiveness When Comparing Alternatively and Traditionally Licensed High School Technology Education Teachers in North Carolina. Journal of Technology Education, 25, 80-98. http://dx.doi.org/10.21061/jte.v25i1.a.6

Brown, G., \& Atikon, M. (2003). Effective Teaching in Higher Education. Translator: Divanyahi, Molook. Islamic Free University Press in Schaloos and Noshaher Noshahr Iran.

Eiszler, C. (2000). College Student's Evaluation of Teaching and Grade Inflation. Research in Higher Education, 43, 483-501.

Evereston, C. M. (1987). Managing Classrooms: A Framework for Teachers. New York: Random House.

Coombs, A. (1971). The Professional Education of Teachers. London: Allyn \& Bacon.

Dabiri, E. O. (2006). Investigating the Method of Teachers Classroom Management Based on Students Gender. Two Journals of New Thoughts of Education.

Devlin, M., \& Samarawickrema, G. (2010). The Criteria of Effective Teaching in a Changing Higher Education Context. Higher Education Research \& Development, 29, 111-124. http://dx.doi.org/10.1080/07294360903244398

Falavel, J. C. (1998). Cognitive Development (Translator: Farhad Maher). Tehran: Agah Press.

Gelaser, Y. (2009). Schools without Fail (Translator: Sadeh Hamzeh, Mozhdeh Hamzeh Tabrizi). Tehran: Roshd Press.

Ghadami, A., Salehi, B., Sajadi, S., \& Naji, H. (2007). Effective Factor on Communicating between Student and Professor from Students' Perspective at University of Medical Science in Arak. Iranian Magazine of Training in Medical Science.

Green, B. A., Miller, R. B., Crowson, H. M., Duke, B. L., \& Akey, K. L. (2004). Predicting High 
School Students' Cognitive Engagement and Achievement: Contributions of Classroom Perceptions and Motivation. Contemporary Educational Psychology, 29, 462-482.

http://dx.doi.org/10.1016/j.cedpsych.2004.01.006

Haerizade, S. A. et al. (2010). Investigation the Effect of Professor-Student Social Relations on Educational Success, Social Science Magazine of Faculty of Literature and Humanities at University of Mashhad.

Hilgard, E., \& Bower, G. N. (1992). Learning Theories (Translator: Mohammad Naghi Brahani). Tehran: Roshd Press.

Hojat Ansari, A. (1995). Investigation the Effect of Mental-Social Conditions of Class in Students' Educational Development in Area 2 and 6 Elementary School, Tehran. MA Thesis, Tehran: University of Tehran.

Hussey, T., \& Smith, P. (2010). Transitions in Higher Education. Innovations in Education and Teaching International, 47, 155-164. http://dx.doi.org/10.1080/14703291003718893

Jones, S. (2003). Measuring the Quality of Higher Education: Linking Teaching Quality Measures at the Delivery Level to Administrative Measures at the University Level. Quality in Higher Education, 9, 223-229. http://dx.doi.org/10.1080/1353832032000151094

Kalahan, J. F. (1989). Training in High-School (Translator: Javad Tahooriyan). Mashhad: Cultural Deputy of Ghods.

Kukuru, J. D. (2011). Expression of Classroom Management Principles by Secondary Schools' Teachers. International Journal of Educational Administration and Policy Studies, 3, 179-190.

Kunter, M., Baumert, J. R., \& Koller, O. (2007). Effective Classroom Management and the Development of Subject-Related Interest. Learning and Instruction, 17, 494-509.

Larocque, L. M. (2008). Assessing Perceptions of the Environment in Elementary Classrooms: The Link with Achievement. Journal of the Association of Educational Psychologists, 24, 289305.

Lizzio, A., Wilson, K., \& Simons, R. (2002). University Students' Perceptions of the Learning Environment and Academic Outcomes: Implications for Theory and Practice. Studies in Higher Education, 27, 27-52. http://dx.doi.org/10.1080/03075070120099359

Lowrin, W. A. (2011). Increasing Teachers Effectiveness in the Process of Teaching (Translator: Mohammad Amini). Tehran: School Press.

Mazloomi Mahmood Abad, S. et al. (2010). Characteristics of a Skillful Instructor from Students Perspective at University of Medical Science of Martyr Sadoughi in Yazad. Hormozgan Medical Magazine.

Miller, I., \& Miller, M. (2004). John E. Freund's Mathematical Statistics with Applications (7th ed.). NY: Prentice Hall.

Mir Mohammadi Mobidi et al. (2012). Effective Factors on Presenting in Classroom from Students Perspective at University of Medical Science in ShahreKord 2013. Iranian Magazine of Education in Medical Science.

Mullins, L. J. (1991). Management and Organizational Behavior. London: Pitman.

Naderi, E., \& Seif Naraghi, M. (1987). Research Methods and How to Evaluate It in the Humanities. Tehran: Arasbaran Publication.

Nazari Vanani, R., Naderi, Z., \& Aeen, F. (2014). Effective Factors Classroom Participation From the Viewpoint of University of Medical Sciences Shahre Kord in 2013. Iranian Journal of Medical Education.

Rahimi, H., Mohammadi, R., \& Hashemiparast, S. M. (2002). Quality Assurance in Higher Education. Concepts, Principles, Practices. Conference on Knowledge-Based Development. 
Rana, R. A., \& Akbar, R. A. (2007). Relationship between Classroom Learning Environment and Student's Achievement in Higher Education. Journal of Education Psychology, 29, 23-48.

Read Abadi, M. et al. (2012). Prioritizing Effective Factors on Effective Teaching from Students View Point: Applying the Process of Hierarchical Analysis (AHP). Iranian Magazine of Training in Medical Science.

Rogers, T. B. (2000). The Psychological Testing Enterprise. New York: Brooks/Cole Pub Co.

Safari, S. (2011). Features of Teaching-Learning Process in Higher Education. Journal of Engineering Education in Iran.

Safavi, A. (2014). General Teaching Methods and Technology. Tehran: Moaser Press.

Salimi, J., \& Ramzani, G. (2014). Identifying Effective Teaching Factor and Evaluating Teaching Status (Case Study at University of Applied Sciences in Kordestan). Journal of Measurement and Evaluation of Training.

Samadi, P. et al. (2008). Processing Condition of Effective Learning Based on Classroom Management Factors in Guidance Schools in Orumiyeh. Two Journal of Modern Educating Thoughts.

Seif, A. A. (2007). Educational Psychology. Tehran: Agah Press.

Seif, A. A. (2011). Modern Education Psychology: Learning and Training Psychology. Tehran: Doran Press.

Shabani, H. (2013). Educational Skills. Tehran: Samt Press.

Shabani, V., Bakhtiyari V., \& Hosein Gholizadeh, R. (2006). Investigation the Quality of Teaching at University. Journal of Research and Programming in Higher Education.

Tajdarai, P. (1990). Scientific Research Methods and Theory, Assessment. Tehran: Publications Eta.

Wang, M. C., Walberg, H. J., \& Herbert, G. D. (1990). What Influences of Learning? A Content Analysis of Review Literature. The Journal of Educational Research, 84, 30-43. http://dx.doi.org/10.1080/00220671.1990.10885988

Weille, K. H., \& Doyle, E. J. (2000). Teacher-Student Interaction: An Exploration of Gender Differences in Elementary Physical Education. Journal of Physical Education, Recreation \& Dance, 71, 43-45.

Wiles, J., \& Bandi, J. (2004). The Management of Supervision and Education Guidance. The Golden Keys of Team Work(2nd ed.). Tehran: Jeihoon Publications. 
Submit or recommend next manuscript to SCIRP and we will provide best service for you:

Accepting pre-submission inquiries through Email, Facebook, LinkedIn, Twitter, etc. A wide selection of journals (inclusive of 9 subjects, more than 200 journals)

Providing 24-hour high-quality service

User-friendly online submission system

Fair and swift peer-review system

Efficient typesetting and proofreading procedure

Display of the result of downloads and visits, as well as the number of cited articles

Maximum dissemination of your research work

Submit your manuscript at: http://papersubmission.scirp.org/

Or contact psych@scirp.org 